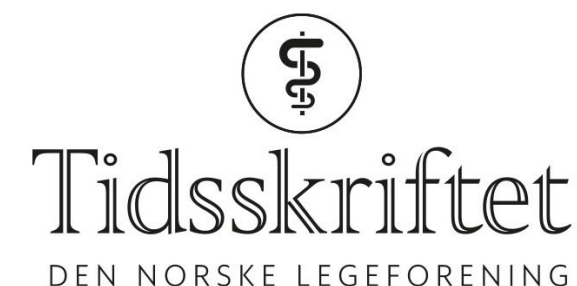

DEN NORSKE LEGEFORENING

\title{
Felles løft for pasienter med nevromuskulære sykdommer
}

DEBATT

\section{SYNNØVE M. JENSEN}

E-post: synnove.magnhild.jensen@unn.no Synnøve M. Jensen er spesialist i nevrologi og overlege ved Nevromuskulært kompetansesenter, Nevro-, hud- og revmatologisk avdeling, Universitetssykehuset Nord-Norge. Hun er Muskelregisterets faglige leder.

Forfatter har fylt ut ICMJE-skjemaet og oppgir ingen interessekonflikter.

\section{KJELL ARNE ARNTZEN}

Kjell Arne Arntzen er ph.d, spesialist i nevrologi og seksjonsoverlege ved Nevromuskulært kompetansesenter, Nevro-, hud- og revmatologisk avdeling, Universitetssykehuset Nord-Norge. Han er leder av Muskelregisterets fagråd.

Forfatter har fylt ut ICMJE-skjemaet og oppgir ingen interessekonflikter.

\section{KRISTIN ØRSTAVIK}

Kristin Ørstavik er dr.med., spesialist i nevrologi og i klinisk nevrofysiologi og overlege ved Enhet for medfødte og arvelige nevromuskulære tilstander og Nevrologisk avdeling, Oslo universitetssykehus. Hun er medlem av Muskelregisterets fagråd.

Forfatter har fylt ut ICMJE-skjemaet og oppgir ingen interessekonflikter.

\section{MAGNHILD RASMUSSEN}

Magnhild Rasmussen er dr.med., spesialist i barnesykdommer og overlege ved Barneavdeling for nevrofag og Enhet for medfødte og arvelige nevromuskulære tilstander, Oslo universitetssykehus. Hun er medlem av Muskelregisterets fagråd.

Forfatter har fylt ut ICMJE-skjemaet og oppgir ingen interessekonflikter.

\section{LAURENCE A. BINDOFF}

Laurence A. Bindoff er professor i nevrologi ved Klinisk institutt 1, Universitetet i Bergen og Nevrologisk avdeling, Haukeland universitetssykehus. Han er tidligere medlem og leder av Muskelregisterets fagråd.

Forfatter har fylt ut ICMJE-skjemaet og oppgir følgende interessekonflikter: Han har mottatt konsultasjonshonorar fra Stealth Biotherapeutics for å sitte i komiteen som avgjør om pasienter skal inkluderes i studier på medisiner mot mitokondriesykdommer, og foredragshonorar fra Santhera.

Landsdekkende oversikt over pasienter med arvelige nevromuskulære sykdommer i Muskelregisteret er viktig for å sikre god behandling. Helseforetakene må hjelpe til med registreringene.

Norsk register for arvelige og medfødte nevromuskulære sykdommer (Muskelregisteret) ble etablert som nasjonalt medisinsk kvalitetsregister i 2008 og har nær tilknytning til nevromuskulær kompetansensetjeneste (1). Registeret omfatter personer med arvelige 
myopatier, nevropatier og spinal muskelatrofi og arvelige kardiomyopatier med kjent assosiasjon til myopati (2).

Hovedformålet med nasjonale medisinske kvalitetsregistre er å måle kvalitet på spesialisthelsetjenestetilbudet i landet, være et styringsverktøy i faglig forbedringsarbeid og helseplanlegging og bidra til kunnskapsutvikling.

For å gjøre systematiske kvalitetsmålinger kreves høy tilslutning blant helseforetakene. Ut fra tall i Norsk pasientregister er det er ca. 4 ooo personer tilgjengelig for registrering. Ved årsskiftet var det 1340 individer i registeret, tilsvarende en dekningsgrad på $33 \%$. Flere helseforetak har null registreringer på årsbasis. Dekningsgrad på diagnosenivå varierer. Spesielt er arvelige nevropatier som Charcot-Marie-Tooths sykdom underrepresentert. Prevalens i Norge kan ifølge en studie være så hyppig som 1:1 214 (3).

Resultater publiseres årlig i form av en årsrapport, som legges ut på kvalitetsregistre.no og muskelregisteret.no. Helseforetakene kan hente ut resultater fortløpende på Rapporteket, en tjeneste i registreringsportalen på helseregister.no. Der kan man holde oversikt over for eksempel antall registrerte med en gitt diagnose som følges opp ved eget helseforetak, om de får den oppfølgingen de skal ha og sammenligne med resten av landet.

\section{Formål og aktualitet}

Det er et stort behov for å kartlegge det norske tjenestetilbudet for populasjonen med arvelige nevromuskulære sykdommer. På det enkleste nivået må vi få vite om hvem som mangler fysioterapibehandling. Noen av sykdommene krever mye mer: Eksempelvis er dystrophia myotonica type 1 (DM1) en stor gruppe med et komplekst oppfølgingsbehov, blant annet pga. kognitiv og nevropsykiatrisk påvirkning som gjør at mange typisk ikke oppsøker hjelp og faller ut fra utdanning og arbeidsliv. Mange pasienter kan ha andre organmanifestasjoner, inkludert risiko for alvorlig hjerteaffeksjon (både arytmier og kardiomyopati), underventilering om natten som krever ventilasjonsstøtte, og øyeproblemer som katarakt. Oppfølging hos kardiolog er derfor obligat, men oppfølging også hos blant annet lungelege og øyelege er viktig. Det foreligger skandinaviske retningslinjer for dystrophia myotonica type 1, Duchennes muskeldystrofi og spinal muskelatrofi, og det bør måles etterlevelse av de viktigste parametrene for helse og livskvalitet. Det er også viktig å kartlegge hvordan diagnosegrupper som mangler retningslinjer blir fulgt opp. I tillegg kan registerdata gi kunnskap om naturlig sykdomsforløp og forekomst helt ned på mutasjonsnivå.

Situasjonen er i ferd med å forandre seg på behandlingsfronten: Fra ren støttebehandling, som fysioterapi og hjelpemidler, er årsaksrettet behandling i form av genmodifiserende terapi blitt en realitet for noen. Dette tilbudet forventes å vokse de nærmeste årene. Med behandlingstilbud vil spesialisthelsetjenesten spille en større rolle enn før, og Muskelregisteret får ny aktualitet. Tidlig diagnostikk og genetisk avklaring blir viktigere når det får behandlingsmessig konsekvens. Behandlingen skal følges opp og effekt dokumenteres og veies opp mot behandlingsulemper og behandlingskostnader. Et eksempel er nusinersenbehandling som er mye omtalt i mediene, en behandling som må gis intratekalt, av og til i narkose, flere ganger i året. Livskvalitetsmålinger blir et viktig supplement til motoriske utfallsmålinger. I tillegg er det nødvendig med observasjon over lang tid, helst gjennom et livsløp, da man ikke kjenner langtidseffektene fullt ut. Med et register kan vi kvantifisere og spore opp personer tilgjengelige for behandling og identifisere dem med uavklart diagnose og bidra til avklaring. Muskelregisteret kan også bidra til kliniske forsøk og forskning gjennom internasjonalt samarbeid og rekruttering til internasjonale/globale registre.

\section{Behov for $\emptyset$ kt registreringsbidrag}

Muskelregisteret blir mer aktuelt med økende fremskritt innenfor diagnostikk og behandling av genetiske sykdommer og i takt med ny kunnskap om hvordan de ulike 
diagnosegruppene skal følges opp. Muskelregisteret har potensial til å bli et viktig målingsog styringsverktøy i forbedringsarbeid for pasientgruppen fremover. Et register krever imidlertid høy tilslutning og dekningsgrad og gode data. Dette kan vi oppnå med et samlet løft. Spesielt viktig er deltakelsen blant nevrologer og barneleger i registreringsarbeidet.

\section{LITTERATUR:}

1. Arntzen K-J, Lund I, Rasmussen M et al. Sammen for pasienter med arvelige nevromuskulære tilstander. Tidsskr Nor Legeforen 2016; 136:1198 - 9. [PubMed][CrossRef]

2. Hasselberg NE, Berge KE, Rasmussen M et al. Kardiomyopati ved arvelig skjelettmuskeldystrofi. Tidsskr Nor Legeforen 2018; 138: doi:10.4045/tidsskr.16.0683. [PubMed][CrossRef]

3. Braathen GJ, Sand JC, Lobato A et al. Genetic epidemiology of Charcot-Marie-Tooth in the general population. Eur J Neurol 2011; 18:39 - 48. [PubMed][CrossRef]

Publisert: 26. september 2018. Tidsskr Nor Legeforen. DOI: 10.4045/tidsskr.18.0630 Mottatt 9.8.2018, godkjent 28.8.2018.

(C) Tidsskrift for Den norske legeforening 2020. Lastet ned fra tidsskriftet.no 